\title{
CENTRAL BANK SWAP LINES AND CIP DEVIATIONS
}

\section{William A. Allen ${ }^{1}$ \\ Gabriele Galati ${ }^{2}$ \\ Richhild Moessner ${ }^{3}$ \\ William Nelson ${ }^{4}$}

${ }^{1}$ National Institute of Economic and Social Research

${ }^{2}$ De Nederlandsche Bank

${ }^{3}$ Bank for International Settlements and National Institute of Economic and Social Research

${ }^{4}$ The Clearing House

NIESR Discussion Paper No. 482

Date: 29 November 2017 


\section{About the National Institute of Economic and Social Research}

The National Institute of Economic and Social Research is Britain's longest established independent research institute, founded in 1938. The vision of our founders was to carry out research to improve understanding of the economic and social forces that affect people's lives, and the ways in which policy can bring about change. Seventy-five years later, this remains central to NIESR's ethos. We continue to apply our expertise in both quantitative and qualitative methods and our understanding of economic and social issues to current debates and to influence policy. The Institute is independent of all party political interests.

National Institute of Economic and Social Research

2 Dean Trench St

London SW1P 3HE

T: +44 (0)20 72227665

E: enquiries@niesr.ac.uk

niesr.ac.uk

Registered charity no. 306083

This paper was first published in November 2017

(c) National Institute of Economic and Social Research 2017 


\section{Central bank swap lines and CIP deviations}

\section{William A. Allen, Gabriele Galati, Richhild Moessner, and William Nelson}

\section{Abstract}

We study the use of US dollar central bank swap lines as a tool for addressing dislocations in the foreign currency swap market against the USD since the global financial crisis. We find that the use of the Federal Reserve's USD central bank swap lines was mainly related to tensions in US money markets during times of financial crisis, and less to tensions which were confined to foreign exchange swap markets. In particular, we find that the use of USD central bank swap lines did not react significantly to the recent period of persistent deviations of covered interest parity (CIP) since 2014. These results are consistent with the view that the Federal Reserve was guided by enlightened self-interest when providing swap lines to foreign central banks, in order to reduce dislocations in US financial markets and support financial stability. In recent years foreign exchange swap markets have not functioned properly, but it appears that now that the crisis is over, the Federal Reserve and other central banks have decided against trying permanently to fill the gap left by the dysfunction in the commercial foreign exchange swap market.

\section{Acknowledgements}

We would like to thank Christina Bräuning, Dion Reijnders and seminar participants at the Bank for International Settlements and at De Nederlandsche Bank for helpful comments. The views expressed are those of the authors and do not necessarily reflect those of De Nederlandsche Bank, the Bank for International Settlements or the Clearing House.

\section{Contact details}

Richhild Moessner (Richhild.Moessner@bis.org) 


\section{Introduction}

We study the use of USD central bank swap lines as a tool for addressing dislocations in the foreign currency swap market against the USD since the global financial crisis, and compare it with their use as a tool for addressing tensions in US financial markets during the crisis. We measure dislocations in the foreign currency swap market by cross-currency basis swap spreads, which indicate deviations from covered interest parity (CIP) if they are non-zero. We measure tensions in US money markets by spreads of US Libor over overnight-index swap (OIS) rates.

During the global financial crisis, central banks responded to the sudden drying-up of liquidity in international financial markets by setting up temporary inter-central-bank swap lines. In December 2007 the Federal Reserve provided inter-central-bank dollar swap facilities to the ECB and the Swiss National Bank, and later extended them also to other central banks (see Allen and Moessner (2010, 2011)), in order to prevent serious disruption to U.S. dollar financial markets. In May 2010, The Federal Reserve re-established temporary swap lines with major central banks (the ECB, the Bank of England, the Bank of Japan, the Bank of Canada and the Swiss National Bank), to provide dollars in response to the international liquidity stresses created by the euro area sovereign debt crisis, as part of coordinated action by major central banks. From 31 October 2013, the Federal Reserve's earlier temporary swap lines with the ECB, the Bank of England, the Bank of Japan, the Bank of Canada and the Swiss National Bank were turned into standing swap lines for US dollar and foreign currency liquidity swaps, at unlimited amounts.

The cross-currency basis is the difference between the interest paid to borrow currency $A$ by borrowing currency $B$ and swapping it for $A$, and the cost of borrowing currency $A$ directly in the cash market. In other words, it measures the cost differential between borrowing in the currency swap market and the money or bond market. If CIP holds, this cross-currency basis should be zero. Before the global financial crisis, only negligible deviations from CIP could be found in the data, even during periods of high volatility (Frenkel and Levich, 1977; Akram et al., 2008; Levich, 2017). Since the global financial crisis, however, there is evidence of significant deviations from CIP. Euro crosscurrency basis swap spreads against the dollar have been so negative that borrowing dollars in the cash market, swapping them for euros and investing the proceeds at euro interest rates could still be profitable (and similarly for swapping dollars for yen) (Sushko et al., 2016). A number of papers has documented CIP deviations during the global financial crisis and the euro area debt crisis (Baba et al., 2008; Baba et al., 2009; Coffey et al., 2009; Griffolli and Ranaldo, 2009; Bottazzi et al., 2012; Ivashina et al., 2015). Du et al. (2016) find that large deviations - for some currency pairs even of the same order of magnitude as the interest rate differential - have persisted also in tranquil markets.

We distinguish three periods, March 2008 to December 2010 including the global financial crisis, the euro area sovereign debt crisis from January 2011 to December 2013, and the period of persistent CIP deviations from January 2014 to January 2017 (see Figure 1 and Du et al., 2016). 
CIP deviations during the global financial crisis and the euro area sovereign debt crisis were primarily due to concerns about bank credit risk, which caused deposit and swap markets to dry up, and a surge of demand for liquidity in US financial markets (Baba and Packer, 2009; Coffey et al., 2009, Allen and Moessner 2010). A number of possible explanations, not mutually exclusive, have been put forward for the persistent CIP deviations from January 2014. They include increased demand to hold assets denominated in US dollars, and decreased demand to have liabilities denominated in US dollars, due to a divergence in monetary policy between the United States and other advanced countries, global banks' reduced appetite for market-making and arbitrage due to regulatory reforms, and a decrease in the supply of US dollars to lend from foreign reserve managers and sovereign wealth funds against the background of declines in commodity prices and emerging currency depreciations. ${ }^{1}$

While the literature has documented the existence of CIP deviations and their possible drivers in recent years since around 2014, the role of USD central bank swap lines in the context of these recent dislocations has not been discussed. Central bank swap lines during the global financial crisis and the euro area sovereign debt crisis, and their effects on CIP deviations, have been studied in Baba, Packer and Nagano (2008), Baba and Packer (2009), Baba and Shim (2010), Moessner and Allen (2013), and Allen and Moessner (2010).

We find that the use of the Federal Reserve's USD central bank swap lines was mainly related to tensions in US money markets, and less to tensions which were confined to foreign exchange swap markets. In particular, we find that the use of USD central bank swap lines did not react significantly to CIP deviations in the recent period of persistent CIP deviations since 2014.

The rest of the paper is structured as follows. Section 2 describes the data, section 3 presents the method and results, and section 4 concludes.

\section{Data}

We measure dislocations in the foreign currency swap market by three-month cross-currency basis swap spreads of the euro against the US dollar, which indicate deviations from CIP if they are nonzero. $^{2}$ We measure tensions in US money markets by the difference between the three-month US Libor rate and the three-month US OIS rate, and tensions in euro money markets by the threemonth euro Libor-OIS spread. ${ }^{3}$ Cross-currency basis swap spreads and Libor-OIS spreads are obtained from Bloomberg at daily frequency, and averaged to obtain a monthly frequency (see Figure 1). We also use three-month euro Libor rates and five-year sterling cross-currency basis swap spread against the US dollar from Bloomberg, with daily data again averaged to obtain a monthly frequency. Our sample period is from March 2008 to January 2017.

USD central bank swap line drawings are obtained from the Federal Reserve website at the weekly frequency, both for total USD swap line drawings and for the ECB's USD swap line drawings, and are averaged to obtain monthly data (Figure 1).

\footnotetext{
${ }^{1}$ See Arai et al. (2016), Avdjiev et al. (2016), Baba and Packer (2009), Du et al. (2016), lida et al. (2016), Sushko et al. (2016) and Wong et al. (2016).

${ }^{2}$ When cross-currency basis swap spreads are non-zero, Rime et al. (2017) find that a narrow set of banks does indeed face risk-less CIP arbitrage opportunities, while arbitrage profits are difficult to obtain for many other players. They argue that segmentation and funding strains in U.S. dollar money markets are the main forces that limit arbitrage activity.

${ }^{3}$ We abstract from possible problems due to misreporting of banks in the LIBOR panels. 


\section{Method and results}

We regress monthly changes in USD central bank swap line drawings, $S L D_{t}$, on lagged monthly changes in three-month cross-currency basis swap spreads of the euro against the USD, $c b s_{t-1}^{E U R}$, and on lagged monthly changes in the three-month US Libor-OIS spread, $\operatorname{LOS}_{t-1}^{U S}$,

$\Delta S L D_{t}=c+a * \Delta c b S_{t-1}^{E U R}+b * \Delta L O S_{t-1}^{U S}+\epsilon_{t}$

where $\Delta$ is the first difference operator applied to monthly data. We regress on lagged, rather than current, changes in cross-currency basis swap spreads in order to partly address endogeneity problems. We use OLS with Newey-West adjusted standard errors to account for serial correlation and heteroskedasticity. We use euro cross-currency basis swap spreads as a measure of dislocations in the foreign currency swap market against the US dollar, since the euro is the obviously-relevant currency during the euro area crisis, and since we have data available since the start of 2008. We use US Libor-OIS spreads as a measure of tensions in US money markets, as is commonly done. We estimate equation (1) for both total USD swap line drawings, and for the ECB's USD swap line drawings.

For total USD swap line drawings, the results of these regressions of equation (1) for the whole sample period from March 2008 to January 2017, for the global financial crisis, the euro area sovereign debt crisis and the period since 2014 are shown in Table 1. We find that total USD central bank swap line drawings reacted significantly to US Libor-OIS spreads during both the global financial crisis and the euro area sovereign debt crisis, but not during the period of persistent CIP deviations since 2014 (Table 1, column1). During the global financial crisis, a widening in the US Libor-OIS spread of $10 \mathrm{bp}$ was associated with an increase in total USD swap line drawings of around USD 11 billion. Moreover, we find that total USD central bank swap line drawings also reacted significantly to changes in euro cross-currency basis swap spreads against the USD during the global financial crisis, with a widening in the spread of $10 \mathrm{bp}$ being associated with an increase in USD swap line drawings of around USD 16 billion, but not during the euro area crisis or during the period of persistent CIP deviations since 2014 (Table 1, column 1).

We also use instrumental variable regressions (GMM) to better address the endogeneity problem. We use lagged changes in three-month US Libor rates and in five-year sterling cross-currency basis swap spreads against the US dollar, and in three-month euro Libor rates, as instrumental variables when estimating equation (1) via GMM. The results for different choices of instrumental variable are shown in columns 2 and 3 of Table 1 . We find that the estimated coefficients of equation (1) regarding the effects of changes in the three-month US Libor-OIS spread are generally robust to using GMM estimation, with the coefficient remaining significant (but becoming somewhat lower) for the whole sample period and during the global financial crisis, and remaining insignificant during the recent period of persistent CIP deviations since 2014; during the euro crisis the coefficient remains significant for the results shown in column 2 , but not for those shown in column 3 . But the coefficient on euro cross-currency basis swap spreads becomes insignificant for the whole sample period and during the global financial crisis when using GMM (columns 2 and 3 of Table 1 ). 
For the ECB's USD swap line drawings, the results of these regressions of equation (1) for the whole sample period from March 2008 to January 2017, for the global financial crisis, the euro area sovereign debt crisis and the period since 2014 are shown in Table 2. We find that the ECB's USD central bank swap line drawings reacted significantly to US Libor-OIS spreads during both the global financial crisis and the euro area sovereign debt crisis, but not during the period of persistent CIP deviations since 2014 (Table 2, column1), as was the case for total USD swap line drawings shown in Table 1. During the global financial crisis, a widening in the US Libor-OIS spread of $10 \mathrm{bp}$ was associated with an increase in the ECB's USD swap line drawings of around USD 3.4 billion. Moreover, we find that the ECB's USD central bank swap line drawings also reacted significantly to changes in euro cross-currency basis swap spreads against the USD during the global financial crisis, with a widening in the spread of $10 \mathrm{bp}$ being associated with an increase in the ECB's USD swap line drawings of around USD 12 billion, but not during the euro area crisis or during the period of persistent CIP deviations since 2014 (Table 2, column1). Again, the pattern is similar to that for total USD swap line drawings shown in Table 1.

For the ECB's swap line drawings, we also use instrumental variable regressions to better address the endogeneity problem, using lagged changes in three-month US Libor rates and in five-year sterling cross-currency basis swap spreads against the US dollar, and in three-month euro Libor rates, as instrumental variables when estimating equation (1) via GMM. The results for different choices of instrumental variable are shown in columns 2 and 3 of Table 2 . As for total swap line drawings, we find for the ECB's USD swap line drawings that the estimated coefficients of equation (1) regarding the effects of changes in the three-month US Libor-OIS spread are generally robust to using GMM estimation, with the coefficient remaining significant (but becoming somewhat lower) for the whole sample period and during the global financial crisis, and remaining insignificant during the recent period of persistent CIP deviations since 2014; during the euro crisis the coefficient remains significant for the results shown in column 2, but not for those shown in column 3 . But for the ECB's swap line drawings, the coefficient on euro cross-currency basis swap spreads remains significant for the whole sample period and during the global financial crisis when using GMM (columns 2 and 3 of Table 2), in contrast to the case of total USD swap line drawings, where it became insignificant for those periods when using GMM.

We also test whether tensions in euro money markets, as measured by three-month euro Libor-OIS spreads, $L O S_{t-1}^{E U R}$, affected USD swap line drawings in addition to US Libor-OIS spreads, by adding lagged changes in the three-month euro Libor-OIS spread in equation (2),

$$
\Delta S L D_{t}=c+a * \Delta c b s_{t-1}^{E U R}+b * \Delta L O S_{t-1}^{U S}+f * \Delta L O S_{t-1}^{E U R}+\epsilon_{t}
$$

again using OLS with Newey-West adjusted standard errors. The results for both total USD swap line drawings and the ECB's USD swap line drawings are shown in Table 3 for the whole sample period. We find in both cases that the coefficient on the three-month euro Libor-OIS spread is not significant, while the coefficient on the three-month US Libor-OIS spread remains significant when the euro Libor-OIS spread is added. We therefore find that both total and the ECB's swap line drawings show no additional reaction to euro Libor-OIS spreads, once euro Libor-OIS spreads and euro cross-currency basis swap spreads are included. We also find when estimating equation (2) for the three subperiods (global financial crisis, euro area crisis and period of persistent CIP deviations since 2014) that the coefficient on the euro Libor-OIS spread is not significant. ${ }^{4}$

\footnotetext{
${ }^{4}$ The results for the subperiods are available on request. 
Our results suggest that total USD swap line drawings mainly react to US Libor-OIS spreads, which measure tensions in US money markets, rather than to cross-currency basis swap spreads, which is consistent with the view that the Fed was guided by enlightened self-interest rather than global altruism when providing swap lines to foreign central banks, in order to reduce dislocations in US financial markets. Moreover, our results suggest that the ECB's swap line drawings were also importantly affected by US Libor-OIS spreads, but reacted to a greater extent to euro cross-currency basis swap spreads during the global financial crisis than total USD swap line drawings. Furthermore, we find that neither total USD swap line drawings nor the ECB's USD swap line drawings reacted to euro cross-currency basis swap spreads in the period of persistent CIP deviations since 2014.

There are several possible reasons why the standing USD Federal Reserve swap lines have been drawn so little as CIP deviations have risen since 2014. The practice of foreign central banks of offering funds at a penalty rate, ie at a rate somewhat above the cost of funds for most banks under normal conditions (Fleming and Klagge, 2010), is likely to deter foreign (i.e. non-U.S.) commercial banks from borrowing dollars from their home central bank. The penalty rate is set by the foreign central bank and can be changed over time; it is not specified by the central bank swap agreement with the Federal Reserve. The foreign central bank can therefore make use of the Federal Reserve swap line more or less attractive by changing the penalty rate it charges. The ECB has offered US dollars in auctions under the bilateral swap line with the Federal Reserve and reduced the penalty rate for swap pricing from $100 \mathrm{bp}$ over the US OIS rate to $50 \mathrm{bp}$ over the OIS rate on 30 November 2011 (ECB, 2014). The ECB stated that "As the sovereign debt crisis intensified in summer 2011, and despite the increase in the EUR/USD cross-currency basis swap, recourse to the US dollar tender operations remained limited, thereby calming market tensions only to a limited extent. This was in all likelihood due to a stigma attached to banks being reliant on central bank funding, in particular when such funding was expensive" (ECB, 2014). These arguments are consistent with Moessner and Allen (2013), who suggest that USD swap lines during the euro sovereign debt crisis were drawn on less than during the global financial crisis because of stigma.

Some central banks may not have authorized or encouraged drawings on swap lines, since they are mainly intended for emergencies, either related to (i) systemic problems of financial stability, or to (ii) a severe liquidity problem at an individual bank. The Federal Reserve stated in a response to frequently asked questions on 'Standing Lines for U.S. Dollar and Foreign Currency Liquidity Swaps from October 2013' published on its website, that these USD swap lines are only intended to be used "during times of market stress":

"What was the purpose of the dollar liquidity swap lines? The dollar liquidity swap lines were designed to improve liquidity conditions in U.S. and foreign financial markets by providing foreign central banks with the capacity to deliver U.S. dollar funding to institutions in their jurisdictions during times of market stress."

"Is the purpose of standing swap lines different from the purpose of temporary swap lines? No. These swap arrangements have helped to ease strains in financial markets and to mitigate their effect on economic conditions. They will continue to support financial stability and to serve as a prudent liquidity backstop." (Federal Reserve, 2017). 
It is widely thought that the swap lines have been made permanent as part of contingency planning for managing the financial stresses that would arise if the U.S. Congress refused to authorise an increase in the Federal debt limit.

The ECB stated in August 2014 that central bank swap lines

"provide central banks with a tool to address adverse market events in foreign currency funding markets and to mitigate negative spillover effects of such tensions on financial stability and the real economy within and across jurisdictions."

"[...] the standing swap lines provide a framework for the reintroduction of US dollar liquidityproviding operations if warranted by market conditions." "[...] the circumstances under which the network of standing swap lines could be activated and the operational modalities of foreign currency liquidity provision have not been specified ex ante." (European Central Bank, 2014)

There was coordination by central banks to phase out US dollar auctions from 2014. The Swiss National Bank stated that

"In view of the substantial improvement in conditions on the market for US dollar liquidity, the SNB has decided, in coordination with other central banks, to phase out its US dollar auctions. Auctions for three-month US dollar liquidity were terminated on 30 April 2014. Auctions for seven-day funding will be held until further notice. The standing swap lines among central banks provide a framework for the reintroduction of US dollar liquidity operations if warranted by market conditions." (Swiss National Bank, 2017)

Since 2014, market dislocations have not been severe enough to pose systemic problems of financial stability, so that central banks are unlikely to have authorized US dollar auctions for reason (i) of systemic problems of financial stability. Individual banks are likely to have been deterred from using the US dollar central bank swap line because of stigma, as well as expected consequential actions by the regulator. Anecdotal evidence from market participants suggests that regulators have made it clear to individual banks that if they were to draw on the US dollar swap line, this would lead to a visit by the regulator to determine what gave rise to the bank's need for drawing on the swap line, and to measures to address the bank's problems.

\section{Conclusions}

In this paper we study the use of USD central bank swap lines as a tool for addressing dislocations in the foreign currency swap market against the USD since the global financial crisis. We find that the use of the Federal Reserve's USD central bank swap lines was mainly related to tensions in US money markets, and less so to tensions just in foreign exchange swap markets. In particular, we find that the use of USD central bank swap lines did not react significantly to CIP deviations in the recent period of persistent CIP deviations since 2014. These results are consistent with the view that the Federal Reserve acted in enlightened self-interest when providing swap lines to foreign central banks, in order to reduce dislocations in US financial markets and support financial stability. 
During the global financial crisis, the Federal Reserve, which was in effect the world's central bank at the time, compensated for the failure of commercial swap markets to function by providing official swaps on a massive scale, which was determined by the needs of the commercial banks which were the ultimate borrowers of the dollars that the Fed provided. Fed swaps were provided on a smaller scale a few years later in the euro area financial crisis. Nearly a decade after the financial crisis ended, foreign exchange swap markets are still not functioning properly. It appears that the Fed and other central banks have decided against trying to fill permanently the gap left by the dysfunction in the commercial foreign exchange swap markets. By doing so, they are leaving an opportunity for new market participants. 
Akram, Q., Rime, D. and L. Sarno (2008), Arbitrage in the Foreign Exchange Market: Turning on the Microscope, Journal of International Economics 76, 237-253.

Allen, W. and R. Moessner (2010), Central bank co-operation and international liquidity in the financial crisis of 2008-9, BIS Working Paper No. 310.

Allen, W. and R. Moessner (2011), The international liquidity crisis of 2008-9, World Economics 12(2), 183-198.

Arai, F., Makabe, Y., Okawara, Y. and T. Nagano (2016), Recent trends in cross-currency basis, Bank of Japan Review, September, 2016-E-7, 1-7.

Avdjiev, S., Du, W., Koch, C. and H. Shin (2016), The dollar, bank leverage and the deviation from covered interest parity, BIS Working Paper No. 592.

Baba, N., and F. Packer (2009), From turmoil to crisis: dislocations in the FX swap market before and after the failure of Lehman Brothers, Journal of International Money and Finance 28(8), 1350-1374.

Baba, N., Packer, F. and T. Nagano (2008), The Spillover of Money Market Turbulence to FX Swap and Cross-Currency Swap Markets, BIS Quarterly Review, March, 73-86.

Baba, N., McCauley, R. and S. Ramaswamy (2009), US Dollar Money Market Funds and Non-US Banks, BIS Quarterly Review, 65-81.

Baba, N. and I. Shim (2010), Policy responses to dislocations in the FX swap market: the experience of Korea. BIS Quarterly Review, June, 29-39.

Bottazi, J., Luque, J., Pascoa, M. and S. Sundaresan (2012), Dollar Shortage, Central Bank Actions, and the Cross Currency Basis, available at https://ssrn.com/abstract=2167716 .

Coffey, N., Hrung, W. and A. Sarkar (2009), Capital Constraints, Counterparty Risk, and Deviations from Covered Interest Rate Parity, Federal Reserve Bank of New York Staff Report No. 393.

Du, W., Tepper, A. and A. Verdelhan (2016), Deviations from covered interest rate parity, NBER Working Paper No. 23170.

European Central Bank (2014), Experience with Foreign currency liquidity-providing central bank swaps, ECB Monthly Bulletin, August, 65-82.

Federal Reserve (2017), available at https://www.federalreserve.gov/monetarypolicy/bst swapfaqs.htm\#5613 (accessed on 1 June 2017), last update of February 16.

Fleming, M. and N. Klagge (2010), The Federal Reserve's Foreign Exchange Swap Lines, Current Issues in Economics and Finance 16(4), April, 1-7, Federal Reserve Bank of New York.

Frenkel, J. and R. Levich (1977), Transaction Costs and Interest Arbitrage: Tranquil versus Turbulent Periods, Journal of Political Economy 85(6), 1209-1226.

Griffolli, T. and A. Ranaldo, 2009, Limits to arbitrage during the crisis: funding liquidity constraints and covered interest parity, Swiss National Bank Working Paper No. 2010-14. 
lida, T., Kimura, T. and N. Sudo (2016), Regulatory reforms and the dollar funding of global banks: Evidence from the impact of monetary policy divergence, Bank of Japan Working Paper No. 16-E-14. Ivashina, V., Scharfstein, D. and J. Stein (2015), Dollar Funding and the lending behaviour of global banks, The Quarterly Journal of Economics, 1241-128.

Levich, R. (2017), CIP Then and Now: A Brief Survey of Measuring and Exploiting Deviations from Covered Interest Parity, Paper presented at the BIS Symposium: CIP - RIP?, Basel, 22-23 May.

Moessner, R. and W. Allen (2013), Central bank swap line effectiveness during the euro area sovereign debt crisis, Journal of International Money and Finance 35, 167-178.

Rime, D., Schrimpf, A. and O. Systad (2017), Segmented Money Markets and Covered Interest Parity Arbitrage, May, mimeo, available at SSRN: https://ssrn.com/abstract=2879904.

Sushko, V., Borio, C., McCauley, R. and P. McGuire (2016), The failure of covered interest rate parity: FX hedging demand and costly balance sheets, Bank for International Settlements Working Paper No. 590.

Swiss National Bank (2017), US dollar auctions conducted by the SNB, available at https://www.snb.ch/en/ifor/finmkt/id/finmkt usdollars (accessed 24 July 2017).

Wong, A., Leung, D. and C. Ng (2016), Risk-adjusted covered interest parity: Theory and evidence, Hong Kong Institute for Monetary Research Working Paper No. 16/2016. 
Figure 1: US dollar swap line drawings (USD million), and 3-month euro cross-currency basis swap spread against the dollar, US Libor-OIS spread and euro Libor-OIS spread (basis points)

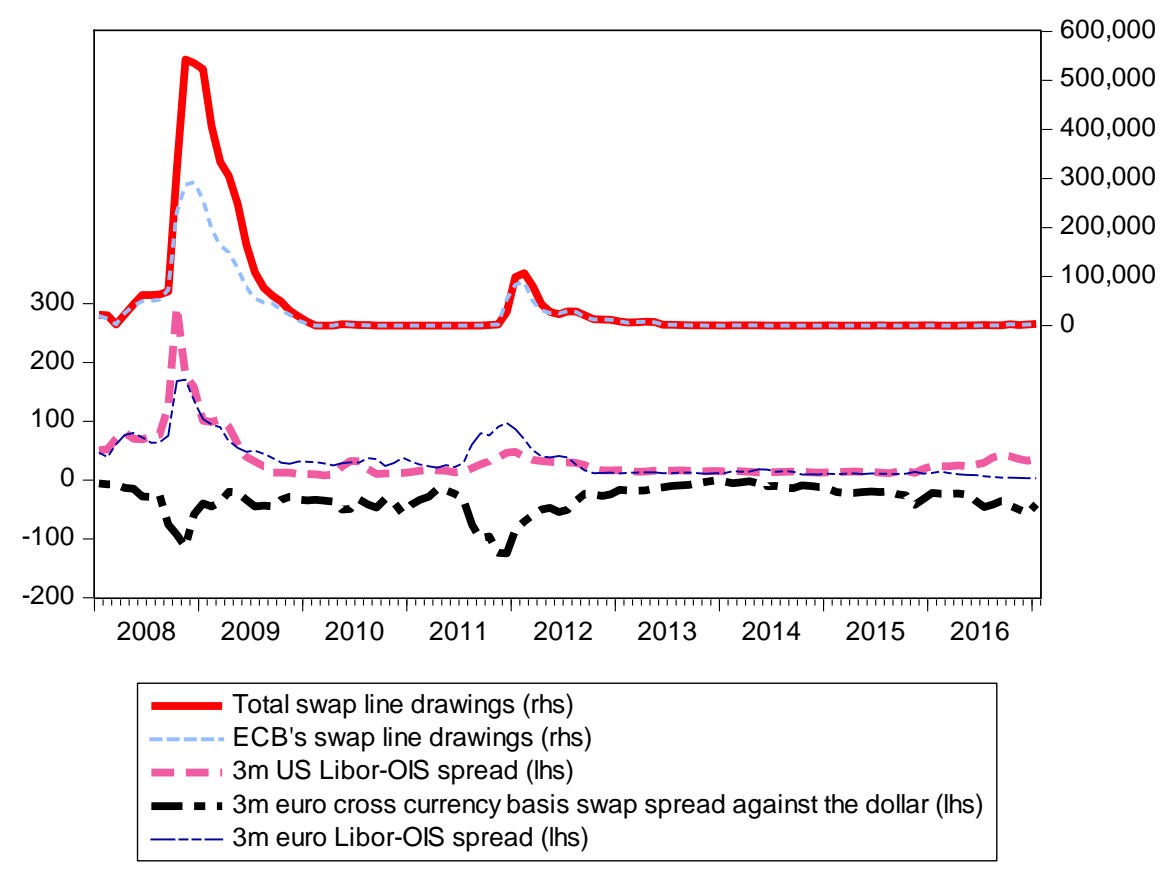

Notes: Monthly averages.

Sources: Federal Reserve, Bloomberg, authors' calculations. 
Tables

Table 1: Regression of monthly changes in total US dollar swap line drawings (in US dollar million) on lagged changes in 3-month euro cross-currency basis swap spread against the US dollar (basis points) and lagged changes in 3-month US Libor-OIS spread (basis points)

\begin{tabular}{|c|c|c|c|}
\hline & 1 & 2 & 3 \\
\hline \multicolumn{4}{|c|}{ March 2008-January 2017} \\
\hline$c$ & -420.9202 & -622.4132 & -522.4765 \\
\hline$\Delta c b s_{t-1}^{E U R}$ & $-914.9082 *$ & -1249.851 & -1047.957 \\
\hline$\Delta L O S_{t-1}^{U S}$ & $1136.644 * * *$ & $885.1260^{* * *}$ & $902.9191^{* * *}$ \\
\hline IVs & No & Yes $^{\mathrm{a}, \mathrm{c}}$ & Yes ${ }^{b, e}$ \\
\hline Adj. $R^{2}$ & 0.575482 & 0.548603 & 0.557595 \\
\hline No. of observations & 107 & 107 & 107 \\
\hline
\end{tabular}

March 2008-December 2010 (Global financial crisis)

\begin{tabular}{llll}
\hline \hline$c$ & -893.5626 & -1770.529 & -645.2884 \\
$\Delta c b s_{t-1}^{E U R}$ & $-1634.360^{*}$ & -2250.218 & -1156.980 \\
$\Delta L O S_{t-1}^{U S}$ & $1065.505^{* * *}$ & $808.1188^{* * *}$ & $895.1072^{* * *}$ \\
\hline \hline$I V s$ & No & Yes $^{\mathrm{a}}$ & Yes $^{\mathrm{b}}$
\end{tabular}
Adj. $R^{2}$
0.637373
0.601501
0.607012

No. of observations

34

34

34

January 2011-December 2013 (Euro area financial crisis)

\begin{tabular}{llll}
\hline$c$ & -462.6122 & -1059.416 & -217.4529 \\
$\Delta c b s_{t-1}^{E U R}$ & 71.96359 & 529.2812 & -153.7014 \\
$\Delta L O S_{t-1}^{U S}$ & $3094.577^{* *}$ & $4313.292^{* * *}$ & 2875.601 \\
\hline \hline IVs & No & Yes $^{\mathrm{a}, \mathrm{d}}$ & Yes $^{\mathrm{b}}$ \\
Adj. $\mathrm{R}^{2}$ & 0.406243 & 0.259061 & 0.370706 \\
No. of observations & 36 & 36 & 36 \\
\hline \hline January 2014-January 2017 & & \\
\hline \hline$c$ & 115.5365 & 165.1988 & 228.1317
\end{tabular}




$\begin{array}{llll}\Delta \operatorname{cbs}_{t-1}^{E U R} & 20.19115 & 53.91518 & 86.25711 \\ \Delta \operatorname{LOS}_{t-1}^{U S} & -17.44186 & -17.96204 & -50.25659\end{array}$

\begin{tabular}{llll}
\hline IVs & No & Yes $^{\mathrm{a}, \mathrm{d}}$ & Yes $^{\mathrm{b}}$
\end{tabular}
Adj. $R^{2}$
$-0.031160$
$-0.128470$
$-0.345582$

No. of observations

37

37

37

$* * *, * *$ and * represent significance at the $1 \%, 5 \%$ and $10 \%$ levels, respectively. Newey-West adjusted standard errors. ${ }^{a}$ Instrumental variables (IVs): lagged changes in 3-month US Libor rate and in 5-year sterling cross-currency basis swap spread against the US dollar; via GMM; ${ }^{b}$ IVs: lagged changes in 3month US Libor and euro Libor rates; via GMM; ${ }^{c / d / e}$ Null hypothesis of weak instruments is rejected at 10\%/15\%/20\% level (Cragg-Donald F-stat, using Stock-Yogo critical values). 
Table 2: Regression of monthly changes in the ECB's US dollar swap line drawings (in US dollar million) on lagged changes in 3-month euro cross-currency basis swap spread against the US dollar (basis points) and lagged changes in 3-month US Libor-OIS spread (basis points)

\begin{tabular}{|c|c|c|c|}
\hline & 1 & 2 & 3 \\
\hline \multicolumn{4}{|c|}{ March 2008-January 2017} \\
\hline$c$ & -415.1624 & -391.3112 & -712.7104 \\
\hline$\Delta c b s_{t-1}^{E U R}$ & $-773.6604^{* *}$ & $-707.9498^{* *}$ & $-1357.245^{* *}$ \\
\hline$\Delta L O S_{t-1}^{U S}$ & $391.0248^{* * *}$ & $342.8653^{* * *}$ & $285.6423^{* * *}$ \\
\hline IVs & No & $Y_{e s}{ }^{a, c}$ & $Y_{e s}^{b, e}$ \\
\hline Adj. $R^{2}$ & 0.453444 & 0.448372 & 0.331330 \\
\hline No. of observations & 107 & 107 & 107 \\
\hline
\end{tabular}

March 2008-December 2010 (Global financial crisis)

\begin{tabular}{llll}
\hline$c$ & -1156.827 & -986.5838 & -1519.866 \\
$\Delta c b s_{t-1}^{E U R}$ & $-1238.912^{* *}$ & $-1020.739^{*}$ & $-1538.854^{*}$ \\
$\Delta L O S_{t-1}^{U S}$ & $337.3473^{* * *}$ & $308.1434^{* *}$ & $266.9172^{* * *}$ \\
\hline \hline IVs & No & Yes $^{\mathrm{a}}$ & Yes $^{\mathrm{b}}$ \\
Adj. $\mathrm{R}^{2}$ & 0.559139 & 0.545261 & 0.537329 \\
No. of observations & 34 & 34 & 34 \\
\hline \hline
\end{tabular}

January 2011-December 2013 (Euro area financial crisis)

\begin{tabular}{llll}
\hline \hline$c$ & -180.9988 & -204.9222 & -317.3031 \\
$\Delta c b s_{t-1}^{E U R}$ & -114.2461 & -118.5282 & -27.36726 \\
$\Delta L O S_{t-1}^{U S}$ & $2298.043^{* *}$ & $2515.376^{* *}$ & 2707.271 \\
\hline \hline IVs & No & Yes $^{\mathrm{a}, \mathrm{d}}$ & $\mathrm{Yes}^{\mathrm{b}}$ \\
Adj. $\mathrm{R}^{2}$ & 0.437248 & 0.433307 & 0.424877 \\
No. of observations & 36 & 36 & 36 \\
\hline \hline January 2014-January 2017 & & \\
\hline c & 96.74767 & 126.6525 & 109.2443 \\
$\Delta c b s_{t-1}^{E U R}$ & 28.21103 & 41.37989 & 32.43362
\end{tabular}




$\begin{array}{llll}\Delta L O S_{t-1}^{U S} & -18.84781 & -40.88858 & -31.95541\end{array}$

IVs No Yes $^{\mathrm{a}, \mathrm{d}}$ Yes $^{\mathrm{b}}$

Adj. $\mathrm{R}^{2}$ $-0.010361$ $-0.022135$ $-0.012823$

No. of observations 37 37 37

$* * *, * *$ and $*$ represent significance at the $1 \%, 5 \%$ and $10 \%$ levels, respectively. Newey-West adjusted standard errors. ${ }^{a}$ Instrumental variables (IVs): lagged changes in 3-month US Libor rate and in 5-year

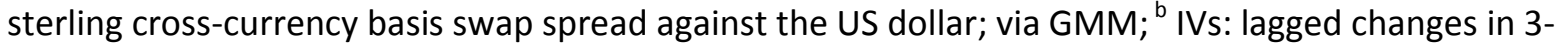
month US Libor and euro Libor rates; via GMM; ${ }^{c / d / e}$ Null hypothesis of weak instruments is rejected at 10\%/15\%/20\% level (Cragg-Donald F-stat, using Stock-Yogo critical values). 
Table 3: Regression of monthly changes in US dollar swap line drawings (in US dollar million) on lagged changes in 3-month euro cross-currency basis swap spread against the US dollar (basis points), in 3-month US Libor-OIS spread and in 3-month euro area Libor-OIS spread (basis points)

\begin{tabular}{|c|c|c|}
\hline & $\begin{array}{l}\text { Total swap line } \\
\text { drawings }\end{array}$ & $\begin{array}{l}\text { ECB's swap line } \\
\text { drawings }\end{array}$ \\
\hline$c$ & -125.4701 & -462.6472 \\
\hline$\Delta c b s_{t-1}^{E U R}$ & -673.0900 & -812.5254 \\
\hline$\Delta L O S_{t-1}^{U S}$ & $956.4300^{* *}$ & $419.9888^{*}$ \\
\hline$\Delta L O S_{t-1}^{E U R}$ & 514.4933 & -82.68948 \\
\hline Adj. $R^{2}$ & 0.579394 & 0.448860 \\
\hline No. of observations & 107 & 107 \\
\hline \multicolumn{3}{|c|}{$\begin{array}{l}* * *, * * \text { and } * \text { represent significance at the } 1 \%, 5 \% \text { and } 10 \% \text { levels, respectively. Newey-West adjusted } \\
\text { standard errors. Sample period: March } 2008 \text {-January } 2017 .\end{array}$} \\
\hline
\end{tabular}

